\title{
The Fistoriography of Queen Victoria: On the Threshold of Private Psychoanalysis and Public Feminism
}

By Rebecca Willis

Queen Victoria was one of the longest rulers in history, and one of the few British women to carry a nation from near revolution to empire in the course of her lifetime. With such an impressive longevity, the Queen saw many events pass by, and experienced many important landmarks in her own life as well. Living through so much rich history, she was one of the most documented monarchs. In this paper, I will critique the historiography of Queen Victoria's life. Too many historians use the psychohistorical method to describe her life; a feminist method is necessary for a new and more accurate historiography.

Commentary, however biased or politicized, was essential to the historicizing of Queen Victoria's life. Most biographers from the $20^{\text {th }}$ and $21^{\text {st }}$ centuries tend to cover her life from a psychoanalytic approach. ${ }^{1}$ Her childhood, marriage, children, and relationship to men are all key factors of her life. Published newspaper articles, political cartoons, portraits, and children's books during her reign in the $19^{\text {th }}$ and early $20^{\text {th }}$ century depict her as a political puppet, as a stubborn, crotchety old woman, as a naive ingénue, as an attractive bride,

1 Lytton Strachey, An Eminent Illustrated Biography: Queen Victoria (London: Harcourt Brace, 1921); John Raymond, ed. Queen Victoria's Early Letters (New York, Macmillan, 1963); Philip Guedalla, The Queen and Mr. Gladstone (New York: Doubleday, 1969); Cecil Woodham-Smith, Queen Victoria: From her Birth to the Death of the Prince Consort (New York, Alfred A. Knopf, 1972); Alison Plowden, The Young Victoria, (New York: Stein and Day, 1983); Kate Williams, Becoming Queen Victoria (New York: Ballantine Books, 2008); Andrew Marr, The Making of Modern Britain: from Queen Victoria to VE Day (London: Pan Books, 2010); Matthew Dennison, Queen Victoria: A Life of Contradictions (New York: St. Martin's Press, 2013); A.N. Wilson, Victoria: A Life, (New York: Penguin Press, 2014). 
and as a worthy symbol of Britain. ${ }^{2}$ Historians such as Dennison, Kinzler, Plowden, Ward, Williams, Wilson, and even screenwriter Fellowes, argued that Victoria was a vivacious spirit who loved her husband, but kept the upper hand over his influence, and mourned his death with in full sanity. ${ }^{3}$ These psychohistorians blamed her character flaws on her structured and sheltered childhood, and on the moral views of Victorian England in terms of marriage and death, to which she entertained for the sake of the people she represented. ${ }^{4}$ Other historians, mainly men from the $20^{\text {th }}$ century such as Bolitho, Guedalla, Raymond, Strachey, Woodham-Smith, and those who edited her published letters and journals posthumously, viewed Victoria as a weak, confused, stubborn, and sometimes mad woman who had to be led her entire life by men who helped her make decisions. ${ }^{5}$ Her paramount role as a wife and mother was lost too soon in the untimely death of her husband, after which she was constantly in a state of depression, being an increasingly ineffective monarch until her death. ${ }^{6}$

Queen Victoria's biographies are told with a psychohistory historiographical view in mind, yet they all seem to differ in various ways. There are certain events throughout her reign that have different causes and effects, depending on the historian's view and how they choose to portray Victoria: her childhood, ascension to the throne, marriage, motherhood, and death of her hus-

2 Samuel G. Goodrich, Peter Parley's Visit to London during the Coronation of Queen Victoria (London: Charles Tilt, 1839); James Bromley, Queen Victoria (London: National Public Gallery, 1834); Margaret Homans and Adrienne Munich, ed., Remaking Queen Victoria (New York: Cambridge University Press, 1997); Henry Tanworth, Queen Victoria Receiving News of Her Accession to the Throne. (National Public Gallery, 1880); Yvonne M. Ward, Censoring Queen Victoria: How Two Gentlemen Edited a Queen and Created an Icon (London: Oneworld, 2014).

3 Dennison, Contradictions, 1-208; Julia Kinzler, "Visualising Victoria: Gender, Genre and History in The Young Victoria (2009)” (Neo-Victorian Studies, 2011), Accessed October 20, 2015, http://www.neovictorianstudies.com/past_issues/4-2\%202011/NVS\%204-2-3\%20J-Kinzler.pdf; Plowden, Young Victoria 1-288; Ward, Censoring, 1-224; Williams, Becoming, 1-465; Wilson, A Life,1-656; The Young Victoria, Directed by Jean-Marc Vallee, Written by Julian Fellowes (London: GK, 2009).

4 Ibid, et al.

5 Hector Bolitho, Albert, Prince Consort (New York, Bobbs-Merrill, 1964); Guedalla, Mr. Gladstone, 1-192; John Raymond, ed. Queen Victoria's Early Letters (New York, Macmillan, 1963); Strachey, Illustrated Biography 1-232; Woodham-Smith, Birth to the Death, 1-495.

6 Ibid, et al. 
band each touch on childhood, sexual adolescence and maturity. Most, however, do not object to the fact that Victoria did live up to the standard of model Victorian womanhood. ${ }^{7}$ Most authors, however deeply they attempt to plunge into her psyche, confirmed she was exactly as the media tends to portray her: a simpering flirt turned regal mother, then batty widow. ${ }^{8}$ Psychohistory may bring new light to historical details, but overall they have not succeeded in cracking the porcelain image of the regal Queen Victoria.

Psychohistory is a method of historiography that is based in psychoanalysis $^{9}$ Freud, as originator/creator/etc. of psychoanalysis, argued that a person's Id, or natural instincts, was under a state of repression from the Superego; civilization's conception of morality and ethics imposed by a child's parents, internalized as they mature, and that a resolution of these desires was needed through sex, repression, or creativity. ${ }^{10}$ The main tenets of Freud's psychoanalysis relied on four characteristics: Childhood influences adult behavior, stages of development, that adult behavior was guided by the unconscious, and that adult behavior could be narrowed down to psychological conflict. ${ }^{11}$ Therefore, facts about the person's childhood and development into adulthood were essential to write their psychobiography or conduct proper psychoanalysis. Further psychologists would take his work into modern fields of social science, including history.

Freud's work paved the way for modern psychology, but Erik Erikson applied Freudian psychology to history as well. ${ }^{12}$ Erikson's work was particularly pivotal in the world of historiography for creating and molding the field of psychobiography by applying psychoanalysis to particular lives in history, adding later psychoanalytical methods like object-relations theory and child

7 Marr, Modern Britain 1-10, Plowden, Young Victoria, 1-288; Williams, Becoming, 1-465; Wilson, A Life, 1-656.

8 Ibid, et al.

9 Sigmund Freud, Civilization and Its Discontents (New York: W.W. Norton and Company, 2010), 1-192.

10 Freud, Civilization, 1-192, and Anna Green and Kathleen Troup, The Houses of History (New York:

New York University Press, 1999): 59-87.

11 Green and Troup, Houses, 60.

12 Ibid, 61. 
development. ${ }^{13}$ Psychohistory was controversial because it was largely speculative. Psychoanalysis relied heavily on evidence of one's childhood, and not every historical figure has such evidence readily accessible or available. Thus, the main critique of psychohistory was that it became too subjective, rather than objective, because the author had to write in their own interpretations as fact. ${ }^{14}$ This was dangerous territory for a historian wishing to be as accurate as possible, especially for such a large historical figure.

Queen Victoria was a fascinating character who has a plethora of evidence about her childhood, being closely guarded as William IV's only heir to the throne. ${ }^{15}$ Her unusually long reign during a time of high advancement of Western civilization made her an intriguing and provoking object of study. ${ }^{16}$ Her nine children and rather exaggerated mourning of her husband Albert implied mental issues that can be interpreted using psychoanalysis. ${ }^{17}$

Victoria's role as a woman in power during an era of strict sexual repression was curious from a Freudian perspective. He held the argument that women were only good for providing a sexual outlet for men and that women held power over men only because they lust for aggression and dominance, sexually. ${ }^{18}$ This theory was widely dismissed as misogynistic by gender theorists and feminists, but it nonetheless persisted in the field of psychohistory, however convoluted and unconscious it may be.

Psychoanalysis was the only field that can truly delve into the underlying issues behind Queen Victoria's psychological behavior, yet there were other options in which historians could interpret her life and impact in a larger historical context. ${ }^{19}$ There was an outpouring of biographies and studies on her life in the mid $-20^{\text {th }}$ century as psychoanalysis became more accepted in the academic

13 Ibid, 61.

14 Ibid.

15 Williams, Becoming, 1-465.

16 Wilson, A Life, 1-656.

17 Dennison, Contradictions, 1-208.

18 Freud, Civilization, 27.

19 Green and Troup, Houses, 59-87. 
world and her letters and diaries became fully accessible to scholars. ${ }^{20}$ Psychobiography provided the bulk of academic works written about her. A variety of historiography on such a great woman is needed: the mainstream empiricism blended in with an overwhelming amount of psychoanalysis to justify her actions is not enough for a complete perspective on Queen Victoria.

A feminist method of history should be more readily applied to the study of Queen Victoria. Too often has Queen Victoria's story been told in the world of men's politics as displayed in the empirical method, and sexual experiments as displayed in the psychohistorical method. As the female role model of an age named after herself, she should enter the female sphere of history as one who made her own mark on history.

Feminist theory was a fairly new historiography, developed during the Second Wave Feminist movement. Joan Scott, a prolific historian during this cultural movement, argued in her work, "Gender: A Useful Category of Historical Analysis," that the word usage of "gender" instead of "sex" left detrimental implications for women in history. ${ }^{21}$ In general, she wanted more feminist, pro-women writers of history to accurately display women's roles throughout the centuries. ${ }^{22}$ She found that women's history has become marginalized into a subcategory of historical writing, like race or hobbies. ${ }^{23}$

Women from the Second Wave Feminist movement concluded that they needed to start writing their own history, to make their own voice known in the academic world as well. ${ }^{24}$ Despite this, most of Queen Victoria's biographers, even those published after this movement, were often men focusing on her sexuality in a psychoanalytical fashion, rather than let a woman try to understand the Victoria's female mind. ${ }^{25}$

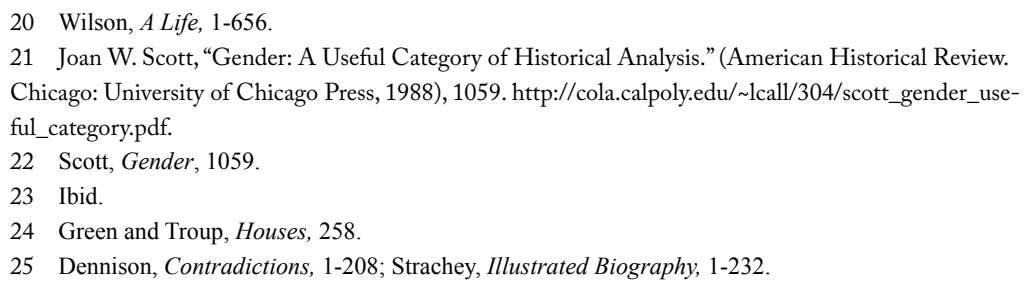


One example of how a feminist historian would be able to better understand Victoria is through Victoria's roles in the private versus public sphere. Traditional gender roles in royal marriages consisted of the man being in charge of state affairs, while the woman managed the household. ${ }^{26}$ These roles were completely reversed in the case of Victoria and Albert; Albert managed the household and family affairs, while Victoria worked in the public sphere as queen. ${ }^{27}$

Most of Queen Victoria's biographies portray her as a very complicated and contradictory queen; in fact, the title of one of her most recent biographies is Queen Victoria: A Life of Contradictions, by Matthew Dennison. ${ }^{28}$ Most of her biographies portray her as the role model for a Victorian woman, yet she seemed to be constantly taken advantage of by other men in power. A psychoanalytical perspective on her life stresses the role of men in her life, and a close retelling of her history and sexual life.

Queen Victoria was historically portrayed as docile and "good" during her younger reign (1837-1861), full of life and vivaciousness. ${ }^{29}$ However, her later reign from 1861-1901, showed her to be both a mourning widow and austere Empress. ${ }^{30}$ The latter portrayal of Victoria was most prevalent in popular culture today, as demonstrated on currency and in political cartoons.

During her reign, England transformed into Great Britain and the United Kingdom, the largest European empire. ${ }^{31}$ Imperialism and colonialism were politically at play - and at the helm, symbolizing the way, was Queen Victoria herself, Empress of India. ${ }^{32}$ The psychohistorical portrayal of Queen Victoria's psychological imbalances regarding her childhood, marriage, and widowhood

26 Green and Troup, Houses, 255.

27 Strachey, Illustrated Biography, 93-179; Dennison, Contradictions, 97; Plowden, Young Victoria, 129-

212; Wilson, A Life, 100; Williams, Becoming, 330-351; Bolitho, Albert 1-216; Woodham-Smith, Birth to the

Death, 123.

28 Dennison, Contradictions, 1-208.

29 Strachey, Illustrated Biography, 1-232.

30 Ibid.

31 Marr, Modern Britain, 1-10.

32 Wilson, A Life, 1-656; Homans, Remaking, 19. 
showed a slightly unhealthy dependence on the men around her: Sir John Conroy, Lord Melbourne, Albert of Saxe-Coburg and Gotha, and her later prime ministers. ${ }^{33}$ The academic world needs a biography about Queen Victoria herself, not about the men who made her. A more feminist approach would venture that Victoria still remained in political control during her entire reign, despite the overwhelmingly dominant male influences she encountered politically, and that she deserves to be celebrated as such today.

Queen Victoria was born the heir to the English throne, a breath of fresh air compared to her debauched and mentally instable predecessors, "born with the breaking of the dawn." ${ }^{34}$ In efforts to change the habitual bad behavior of kings before her, her mother, the Duchess of Kent, and their steward, Sir John Conroy, implemented the Kensington system. ${ }^{35}$ It restricted Victoria's exposure to 'worldly' novels, and never allowed her to be out of the sight of an adult. ${ }^{36}$ While it was established as a way of ensuring that England's future queen would be less debauched, it could be argued that Sir John Conroy used the Duchess of Kent's vulnerability to his advantage. ${ }^{37}$ The motives of Conroy's character are unclear, but he was most often villainized, while Victoria was victimized, which important for the study of her childhood. ${ }^{38}$

Most official historians, such as Williams, stated Victoria enjoyed a docile, tranquil childhood before blossoming gracefully into womanhood and queenhood simultaneously. ${ }^{39}$ Still, other sources describe the princess as bellicose, obstinate, and hard to manage - which was it? ${ }^{40}$ Victoria's character and behavior as a child would make a great deal of difference if one were to study her relationships with Conroy, her mother, her uncle King Leopold of Belgium,

33 Ibid; Strachey, Illustrated Biography, 1-232.

34 Dennison, Contradictions, 8.

35 The Young Victoria, Fellowes pg. 5; Woodham-Smith, Birth to the Death, 63; Dennison, Contradictions, 23-25; Williams, Becoming, 171-288; Wilson, A Life, 43; Plowden, Young Victoria, 23-147; Strachey, Illustrated Biography, 25-48.

36 Ibid, et al.

37 Ibid, et al.

38 The Young Victoria, Fellowes; Kinzler, Visualising Victoria; Plowden, Young Victoria, 1-288.

39 Dennison, Contradictions, 23-25; Williams, Becoming, 171-288; Plowden, Young Victoria, 23-147.

40 Strachey, Illustrated Biography, 25-48; Wilson, A Life, 43; Woodham-Smith, Birth to the Death, 63. 
and her governess, Baroness Lehzen. The men who wrote Victoria's history using psychoanalyst terms portrayed Victoria as a victim of powerful influence, especially from her governess Baroness Lehzen, because of their close relationship. ${ }^{41}$ However, there is a major discrepancy in writing between one of her oldest psychobiographers, Lytton Strachey, and her most recent biographer, Dennison. Strachey stated that all of Victoria's influencers shaped her in such a way that they themselves were, in effect, ruling through her, since she was a weak woman, led by emotion rather than fact. ${ }^{42}$ Recent biographers side with a more feminist view that Victoria was her own woman, with her own brain and will to rule effectively, were it not for Victorian social conventions. ${ }^{43}$ Historians agreed that Victoria longed to be rid of the chains of the Kensington system when she ascended to the throne at age eighteen. ${ }^{44}$ The literature of her ascension rings of national rejoicing, a fresh start for the monarchy. ${ }^{45}$ Portraiture during her reign depicted a glorious queen-turned-goddess. ${ }^{46}$ Even modern filmmaker Julian Fellowes wished to imitate this portrait in his film The Young Victoria, as booming angelic choirs herald England's glory ${ }^{47} \mathrm{Her}$ diaries were full of the word 'alone' after she ascended the throne; her rebellion against the Kensington system was now in effect. ${ }^{48}$ Psychohistorians found ample source material for analysis of her unique childhood.

Victoria's coronation was also described with similar sentiment; her "goodness" in wanting to give her dog his bath was almost always mentioned because it showed her as a caring ruler. ${ }^{49}$ Yet, during the ceremony, $19^{\text {th }}$ century historians describe her as overwhelmed by the crowd: tearful, quiet and frail..$^{50}$

41 Strachey, Illustrated Biography, 59; Bolitho, Albert, 1-216.

42 Strachey, Illustrated Biography, 1-232.

43 Williams, Becoming, 4, 367; Dennison, Contradictions, 90-95; Kinzler, Visualising Victoria; The Young Victoria, Fellowes.

44 Ibid; Woodham-Smith, Birth to the Death, 1-232.

45 Ibid.

46 Tanworth, Receiving News; Goodrich, Peter Parley.

47 The Young Victoria, Fellowes, 4.

48 Bolitho, Albert, 1-216; Williams, Becoming, 1-465.

49 Strachey, Illustrated Biography, 57-68; Goodrich, Peter Parley, 10-20.

50 Ibid, et al. 
Victorian historians portrayed Victoria as weak and womanly, especially those who wished for a republican government, yet psychohistorians seem to gloss over this literature, saying instead that the ceremony was a logistical disaster, or that her Prime Minister Lord Melbourne pressured her to perform perfectly. ${ }^{51}$ In any case, the public-swore their loyalty to the "Lilliputian beauty" who now sat on the throne. ${ }^{52}$

Victoria's ministers were always concerned about who was permitted to influence the queen with their ideas. ${ }^{53}$ Victoria's amiable correspondence with her uncle King Leopold of Belgium was under careful scrutiny, as was her governess Baroness Lehzen's correspondence with Baron Stockmar. ${ }^{54}$ Sir John Conroy miserably failed at using his influence to his advantage, which Victoria knew full well. ${ }^{55}$ The Viscount Lord Melbourne, Victoria's first Prime Minister and mentor, was given a tremendous amount of sway over Victoria, according to most male psychohistorians. ${ }^{56}$ These authors blame the Kensington system for Victoria's seeming need for male leadership in her life, yet they also praised how amiable of a relationship Victoria and Melbourne had compared to her later Prime Ministers. ${ }^{57}$

Psychohistorians almost always imply that Victoria's relationship with Melbourne was more than just a professional one; they shared a level of emotional intimacy that can only come from a man's sexual repression and a woman's innocence. ${ }^{58}$ Feminist authors would most likely beg to differ. They could argue that not every male relationship Victoria encountered up to this point would look any different; she was just naturally an affectionate woman. She may never have interacted with her father, but Sir John Conroy and King Leopold

51 Woodham-Smith, Birth to the Death, 97.

52 Homans, Remaking, 24.

53 Wilson, A Life, 1-656; Strachey, Illustrated Biography, 1-232; Woodham-Smith, Birth to the Death, 1-232; Ward, Censoring.

54 Ibid.

55 The Young Victoria, Fellowes; Dennison, Contradictions, 37; Plowden, The Young Victoria, 1-288.

56 Ibid, Bolitho, Albert, 1-216; Wilson, A Life, 1-656.

57 Strachey, Illustrated Biography, 49; Wilson, A Life, 1-656; Williams, Becoming, 1-465; Guedalla, Mr. Gladstone, 1-192.

58 Dennison, Contradictions, 1-208. 
had tried similar tactics which failed, she gained full control of her ability to rule despite Melbourne's efforts to control her opinions. ${ }^{59}$ The Young Victoria almost achieved this view when she grilled Melbourne to give her statistics on the rising industrial classes, much to his chagrin. ${ }^{60}$ The public dislike Lord Melbourne's influence since he was a member of Parliament and a liberal. ${ }^{61}$

The most controversial influence of all was Albert of Saxe-Coburg and Gotha, Prince Consort to Queen Victoria. Psychohistorians consider Albert the man in charge while Victoria was in an almost constant state of pregnancy during their marriage. ${ }^{62}$ In reality, feminist authors would not depict Victoria giving up her role without a fight. The public disliked Albert from the start for being German, and therefore "un-English." ${ }^{63}$ Sources eventually disagreed over Albert's true role as a husband. Male psychohistorians always look for ways that King Leopold of Belgium tried to influence Albert, and that Albert was merely his agent for rule. ${ }^{64}$ Instead of searching for influencers over Victoria, Victoria's ruling style herself was left aside. ${ }^{65}$ Albert either ruled in Victoria's stead because he was power hungry, or because of duty to his wife. Ultimately, a feminist historian would stress the idea that Victoria and Albert's traditional gender roles were reversed: Victoria ruled in public, while Albert managed the private household. ${ }^{66}$

Motherhood was worshipped by the English Victorians; they admired Victoria and constantly labeled her as the "mother of Europe." ${ }^{77}$ What most psychohistorians brush past, and what most feminist historians should spend more time with, was Victoria's reaction to having children. She was upset when she discovered she was pregnant, and she found children a hindrance from her

59 Plowden, Young Victoria, 1-288, Williams, Becoming, 1-465; The Young Victoria, Fellowes.

60 The Young Victoria, Fellowes.

61 John Doyle, The Balance of Power, Lithograph. (London: Thomas McLean, 5 June 1839); John Doyle, The

Duenna. (Lithograph. London: Thomas McLean, 1838).

62 Williams, Becoming, 1-465; Wilson, A Life, 1-656; Strachey, Illustrated Biography, 1-232.

63 Strachey, Illustrated Biography, 78.

64 Ibid.

65 Ibid.

66 Williams, Becoming, 1-465; Wilson, A Life, 1-656; Dennison, Contradictions, 1-208.

67 Homans, Remaking, 1. 
work. At one point, she even expresses her desire to abort her pregnancy ${ }^{68}$ Yet for the sake of the nation, and Victoria's current family on the throne, she is typecast as a mother-figure. Feminist historians would be able to note the marginalization of this role and further extrapolate upon it-how women were always confined to their sexuality and how it affects their public role. Victoria's public role should (if she had her way) be queen, yet, because of her gender, she was labeled as the mother of England.

Victoria's marriage, however ambiguous, came to a sudden close when Albert died in $1861 .{ }^{69}$ Psychohistorians noted this date as a major turning point in Victoria's life, one from which she would never fully recover. Certain authors stated that her mourning was justified, as any dutiful wife would have at that time, while others sided with England and said that it was far too drawn out. ${ }^{70}$ In either case, psychohistorians question her sanity, as did many of the queen's ministers. ${ }^{71}$ Mental illness ran in her family, which gave reason for a psychoanalytical approach, yet a gender power play was present when a woman was described to be mentally ill or hysterical, especially at a time when it would be expected of her to act as such. ${ }^{72}$ Much research from a female gender historian is needed for Victoria's latter, post-Albert half of her reign- to discuss her role as a widow and queen, and to understand the uniquely marginalized lifestyle of a woman accused of mental instability. Psychohistorians disregard much of her adult life as a time of insomnia, when her ministers took over power and she was passively labeled as England's representative and "the grandmother of Europe."73

Even those writing specifically about her time of mourning describe it as a "cult of death." ${ }^{74}$ In reality, what very few psychohistorians realized, was that

68 Williams, Becoming, 351.

69 Strachey, Illustrated Biography, 93.

70 Dennison, Contradictions, 1-208; Strachey, Illustrated Biography; Wilson, A Life; Williams, Becoming, $1-465$.

71 Williams, Becoming, 1-465.

72 Strachey, Illustrated Biography, 1-232.

73 Ibid.

74 Ibid, Williams, Becoming, 1-465 and Wilson, A Life, 1-656. 
Victoria did recover from Albert's death and ruled effectively through rather difficult prime ministers; she kept her monarchy afloat when some wished to be rid of it altogether and expanded England into the British Empire. ${ }^{75}$ This woman was capable to do it all, much to the adoration of her subjects, and even worshipped as 'the Second Gloriana' like her predecessor Elizabeth I. ${ }^{76}$ England would not be the same without her active and effective rule, despite what theoretical psychological history indicated she may have endured. What was more historically effective was the fact that she was a female ruler during a time of extreme sexual repression. ${ }^{77}$ Only a truly feminist history could fully capture the effect of her image in her public role as a woman.

Instead, men wrote Victoria's history for her. Letters published upon the passing of her death serve as her first biography- screened by men, including her son King Edward VII, who had a famously tempestuous relationship with her. "Queen Victoria...is the product of her biographers." ${ }^{78}$ Thus, not enough work has been done to uncover the 'true' Victoria.

While Queen Victoria's childhood under the "Kensington System" made separation with her husband Albert a psychological issue for the rest of her life, one that her political leaders exploited to perform their own visions of Empire and colonial expansion, she was genuinely a vivacious soul, eager to rule effectively and care for her subjects. ${ }^{79}$ She moved on from her husband's death into a more mature role: fulfilling the part of a second "Gloriana" by those who sought a strong nationalist expansion under her rule, but with full consciousness and command. ${ }^{80}$ During her reign, she maintained control of her person within the limitations of any Victorian woman at the time. It is time to stop seeing Victoria as a weakling, influenced by everyone else around her. A pro-female approach to Victoria is long overdue, especially one with details of gender politics.

75 Plowden, Young Victoria, 1-288; Marr, Modern Britain, pg. 1-10; Dennison, Contradictions, 1-208.

76 Homans, Remaking, 20-48.

77 Marr, Modern Britain, pg. 1-10.

78 Ward, Censoring, 1.

79 Marr, Modern Britain, 1-10; Wilson, A Life, 1-656; Dennison, Contradictions, 1-208; Kinzler, Visualizing Victoria.

80 Ibid; Homans, Remaking. 


\section{BIBLIOGRAPHY}

Bolitho, Hector. Albert, Prince Consort. New York, Bobbs-Merrill, 1964.

Bromley, James. Queen Victoria. London: National Public Gallery, 1834.

Dennison, Matthew. Queen Victoria: A Life of Contradictions. New York: St. Martin's Press, 2013.

Doyle, John. The Balance of Power. Lithograph. London: Thomas McLean, 1839. . The Duenna. Lithograph. London: Thomas McLean, 1838.

Freud, Sigmund. Civilization and Its Discontents. New York: W.W. Norton and Company, 2010. Goodrich, Samuel G. Peter Parley's Visit to London during the Corona tion of Queen Victoria. London: Charles Tilt, 1839.

Green, Anna and Troup, Kathleen. The Houses of History: A Critical Reader in Twentieth-Century and Theory. New York: New York University Press, 1999.

Guedalla, Philip. The Queen and Mr. Gladstone. New York: Doubleday, 1969.

Homans, Margaret and Adrienne Munich, ed. Remaking Queen Victoria. New York: Cambridge University Press, 1997. Google Scholar. Web. Accessed October, 202015.

Kinzler, Julia. "Visualising Victoria: Gender, Genre and History in The Young Victoria (2009)”. Neo-Victorian Studies 4:2 (2011). Web. Accessed October 20, 2015. http://www.neovictorianstudies.com/past_issues/4-2\%202011/NVS\%20 4-2-3\%20J-Kinzler.pdf.

Marr, Andrew. The Making of Modern Britain: from Queen Victoria to VE Day. London: Pan Books, 2010.

Plowden, Alison. The Young Victoria. New York: Stein and Day, 1983.

Raymond, John, ed. Queen Victoria’s Early Letters. New York: Macmillan, 1963.

Scott, Joan W. "Gender: A Useful Category of Historical Analysis." American Historical Review. Chicago: University of Chicago Press, 1988. http://cola. calpoly.edu/ 1call/304/scott_gender_useful_category.pdf. 
Strachey, Lytton. An Eminent Illustrated Biography: Queen Victoria. London: Harcourt Brace, 1921.

Tanworth, Henry. Queen Victoria Receiving News of Her Accession to the Throne. National Public Gallery, 1880.

Ward, Yvonne M. Censoring Queen Victoria: How Two Gentlemen Edited a Queen and Created an Icon. London: Oneworld, 2014.

Williams, Kate. Becoming Queen Victoria. New York: Ballantine Books, 2008.

Wilson, A.N. Victoria: A Life. New York: Penguin Press, 2014.

Woodham-Smith, Cecil. Queen Victoria: From her Birth to the Death of the Prince Consort. New York, Alfred A. Knopf, 1972.

The Young Victoria. Directed by Jean-Marc Vallee, Written by Julian Fellowes. London: GK, 2009. DVD. http://www.pages.drexel.edu/ ina22/vsplaylib/Screen play-Young_Victoria,\%20The.pdf. 